\title{
PENGUKURAN BEBAN KERJA KARYAWAN MENGGUNAKAN METODE NASA-TLX DI PT. TRANKA KABEL
}

\author{
Ratih Ikha Permata Sari \\ Program Studi Teknik Industri, FTMIPA \\ Universitas Indraprasta PGRI, Jakarta \\ Email : ratih.ikha@gmail.com
}

\begin{abstract}
PT. Tranka Kabel is the first cable manufacturing company in Indonesia that provides power lines and telephones. This study aims to determine the workload on quality control employees. Problems arising from work load on employees impact on concentration, performance, achievement and motivation, sleep quality at rest at home, health and work accident. The method used in this study is the measurement of mental workload using NASA-TLX (Task Load Index) with two stages: the weighting stage and ranking stage. Initial research results obtained the value of WWL (weighted workload) of morning shift employees of 73.75, day shift 74.94 and night shift 77.00 the results experienced a high mental workload. Proposed improvements were made with improved shift work, the application of music therapy and aromatherapy. The evaluation result of the implementation of the improvement suggest the value of WWL (weighted workload) of morning shift employee is 56,31, afternoon shift 57,40, night shift 58,41 result decrease mental work load.
\end{abstract}

Keywords: Workload, Nasa-TLX, employees of PT. Tranka Cable

\begin{abstract}
ABSTRAK
PT. Tranka Kabel adalah perusahaan manufaktur kabel pertama di Indonesia yang menyediakan kabel listrik dan telepon. Penelitian ini bertujuan untuk mengetahui beban kerja pada karyawan quality control. Permasalahan yang timbul akibat beban kerja pada karyawan berdampak pada konsentrasi, kinerja, prestasi dan motivasi, kualitas tidur saat istirahat di rumah, kesehatan dan kecelakaan kerja. Metode yang digunakan dalam penelitian ini adalah pengukuran beban kerja mental menggunakan NASA-TLX (Task Load Index) dengan dua tahap yaitu tahap pembobotan dan tahap pemberian peringkat. Hasil penelitian awal diperoleh nilai WWL (weighted workload) karyawan shift pagi sebesar 73,75, shift siang 74,94 dan shift malam 77,00 hasilnya mengalami beban kerja mental tinggi. Usulan perbaikan dilakukan dengan perbaikan shift kerja, penerapan terapi musik dan aromaterapi. Hasil evaluasi terhadap implementasi usulan perbaikan menunjukkan nilai WWL (weighted workload) karyawan shift pagi sebesar 56,31, shift siang 57,40, shift malam 58,41 hasilnya mengalami penurunan beban kerja mental.
\end{abstract}

Kata kunci: Beban Kerja, Nasa-TLX, karyawan PT. Tranka Kabel 


\section{PENDAHULUAN}

Pada dasarnya, aktivitas manusia dapat dibagi menjadi dua golongan, yaitu kerja fisik (otot) dan kerja mental (otak). Walaupun tidak dapat dipisahkan, namun masih dapat dibedakan pekerjaan dengan dominasi aktifitas fisik dan pekerjaan dengan dominasi aktivitas mental. Aktivitas fisik dan mental ini menimbulkan konsekuensi, yaitumunculnya beban kerja. Beban kerja merupakan perbedaan antara kemampuan pekerja dengan tuntutan pekerjaan (Meshkati \& Hancock, 1988).Apabila kemampuan dari pekerja lebih tinggi daripada tuntutan pekerjaan maka akan menimbulkan rasa bosan dan sebaliknya, apabila kemampuan pekerja lebih rendah daripada tuntutan pekerjaan maka akan menimbulkan dampak kelelahan yang berlebih yang menyebabkan stress kerja pada karyawan dan menyebabkan sering terjadinya kecelakaan kerja dan kecacatan produk. Hal ini menyebabkan keuntungan perusahaan berkurang.

PT. Tranka Kabel merupakan perusahaan manufaktur yang menyediakan kabel listrik dan telepon. Penyebab beban kerja mental yang dihadapi karyawan antara lain target pengukuran dan pengecekan kabel, pembagian waktu/shift kerja yang tidak teratur, faktor lingkungan kerja (kebisingan, temperatur, pencahayaan, dll). Sehingga dilakukan perbaikan shift kerja, penerapan terapi musik dan aromaterapi yang hasilnya dapat menurukan beban mental karyawan.

Istilah "ergonomic" berasal dari bahasa Latin yaitu Ergon (Kerja) dan Nomos (Hukum Alam) dan dapat didefinisikan sebagai studi tentang aspek- aspek manusia dalam lingkungan kerjanya yang ditinjau secara anatomi, fisiologi, psikologi, engineering, manajemen, dan desain/perancangan.

Di dalam ergonomi dibutuhkan studi tentang sistem dimana manusia, fasilitas kerja, dan lingkungannya saling berinteraksi dengan tujuan utama yaitu menyesuaikan suasana kerja dengan manusianya. Ergonomi disebut juga sebagai "Human Factors". Ergonomi juga digunakan oleh berbagai macam ahli/profesional pada bidangnya, misalnya ahli anatomi, arsitektur, perancangan produk industri, fisika, fisioterapi, terapi pekerjaan, psikologi dan teknik industri.

Menurut Gopher dan Donchin (1986) serta Kantonwitz dan Casper (1988), mendefinisikan beban kerja sebagai perbedaan antara tuntutan pekerjaan termasuk lingkungan kerja dan kemampuan pekerja untuk memenuhi tuntutan tersebut. Hart (1986), menyatakan bahwa beban kerja mental adalah usaha atau biaya yang dikeluarkan manusia untuk mencapai performansi yang diharapkan. Sanders dan McCormick (1993), mendefinisikan beban kerja sebagai tuntutan fisik atau mental dari pekerjaan terhadap seseorang ketika melakukan pekerjaan tersebut, yang ditunjukkan dengan kapasitas tertentu.

Terdapat empat faktor penyebab tambahan beban kerja mental, antara lain :

1. Faktor fisik, yang meliputi : bahan baku, peralatan, penerangan, dan suhu

2. Faktor kimia, yaitu meliputi : debu, cairan pelarut misalnya spirtus, cairan pewarna misalnya cat, pelitur, serta benda kimia padat seperti dempul

3. Faktor fisiologis, yang meliputi : kontruksi mesin, sikap, dan cara kerja

4. Faktor psikologis, yaitu meliputi : suasana kerja, hubungan antara pekerja maupun dengan pengusaha, pemilihan kerja, dan lainlain.

Faktor-faktor tersebut dapat mengganggu daya kerja seorang tenaga kerja, yaitu :

1. Penerangan yang kurang cukup intensitasnya dapat menyebabkan kelelahan mata

2. Kegaduhan mengganggu daya ingat, konsentrasi pikiran, berkaitan kelelahan psikologis

3. Debu-debu yang dihirup ke paru-paru mengurangi penggunaan optimal alat pernafasan untuk mengambil oksigen dari udara

4. Sikap badan yang salah mengurangi hasil kerja menyebabkan timbulnya kelelahan atau kurang maksimalnya alat-alat tertentu.

Menurut Yulianti, 2000, stress kerja dikonseptualisasi dari beberapa titik pandang, yaitu stres sebagai stimulus, stres sebagai respon, dan stres stimulus-respon. Stres sebagai stimulus merupakan pendekatan yang menitikberatkan pada lingkungan. Definisi stimulus memandang stres sebagai suatu kekuatan yang menekan individu untuk memberikan tanggapan terhadap stesor. Pendekatan ini memandang stres sebagai konsekuensi dari interaksi antara stimulus lingkungan dengan respon individu. Stres dipandang tidak sekedar sebuah stimulus atau respon, melainkan stres merupakan hasil antara kondisi stimulus lingkungan dan kecendrungan individu untuk memberikan tanggapan. 
Stoner (1986) mengatakan bahwa pekerjaan yang berbeda bagi setiap pekerja akan menimbulkan tingkat stress kerja yang berbeda pula. Stres kerja berpengaruh nsecara langsung maupun tidak langsung terhadap aspek-aspek pekerjaan terutama terhadap motif berprestasi yang akan berhubungan dengan proses kerja.

Menurut (Dadang Hawari, 2004), apabila terjadi stres, kecemasan, kegelisahan, maka tubuh akan bereaksi secara otomatis berupa perangsangan hormone, dan neurotransmitter. Untuk menahan stressor, penting untuk mempertahankan kondisi mental, dan fisik makluk hidup. Untuk meningkatkan kekebalan stes ada beberapa pengelolaan terhadap stress, yaitu :

\section{Olah raga}

Olah raga yang teratur minimal 2 kali seminggu, tubuh dapat lebih bugar, dan lebih sehat sehingga mental, dan kekebalan tubuh dapat lebih meningkat

2. Rekreasi

Rekreasi dapat membebaskan diri dari kejenuhan pekerjaan atau kehidupan yang monoton, dan dapat memulihkan ketahanan fifik, dan mental. Rekreasi dapat dilakukan bersama pasangan, dan bersama keluarga, sehingga sarana komunikasi diantara anggota keluarga dapat berjalan efektif, mempererat hubungan psikososial diantara anggota keluarga

3. Kasih sayang

Perhatian terhadap anak, istri, atau suami, hubungan harmonis yang terus terjaga akan memberikan ketentraman batin, dan kedamaian. Penelitian menunjukkan bahwa $80 \%$ stres disebabkan oleh adanya masalah dalam hubungan antara suami istri, dan merupakan faktor dominan bagi menurunnya daya tahan atau kekebalan seseorang terhadap stress.

\section{Sosial Ekonomi}

Pengelolaan keuangan yang baik tidak akan memberi dampak stres, apalagi bila tidak dapat mengatur pengeluaran yang lebih besar pasak dari pada tiang, atau mengejar status tanpa melihat kemampuan, dan penghasilan

\section{Rokok}

Penelitian membuktikan bahwa, tidak merokok lebih dari 10 batang sehari, dan lebih dari itu tubuh tidak akan mampu menetralisir efek negative rokok. Setiap satu batang rokok, usia diperpendek 12 menit

6. Pergaulan, atau silahturahim

Manusia tidak dapat hidup tanpa manusia lainnya karena manusia adalah makhluk sosial yang memerlukan teman, sahabat, dan tempat bertukar pikiran

7. Tidur

Tidur yang teratur 7-8 jam sehari sangat baik untuk memulihkan segala kelelahan fisik, dan mental. Apabila kurang tidur, maka daya tahan tubuh akan menurun, badan tidak bugar, pekerjaan menjadi tidak lancer. Maka kekebalan tubuh kita terhadap stres akan berkurang

8. Makanan

Makan yang seimbang, dan teratur dapat memberi dampak bagi kesehatan fisik, dan kekebalan tubuh

9. Waktu

Pengelolaan waktu yang baik, seperti : waktu menonton TV untuk menghilangkan kejenuhan di kantor, membaca buku untuk menambah ilmu pengetahuan, dan memanfaatkan waktu untuk beristirahat di rumah.

10. Agama

Penghayatan agama yang baik akan memberikan dampak terhadap bagaimana memaknai hidup, kemantapan beragama membawa kepada ketenangan hidup. Pemahaman yang salah terhadap sesuatu yang musyrik, dapat membuat manusia terjebak terhadap perilaku yang tidak benar, sehingga pemahaman spiritual tercampur dengan batil.

\section{Shift Kerja}

Shift kerja adalah pembagian kerja yang dilakukan untuk mengelola waktu selama 24 jam dalam sehari dalam tiga shift, antara lain : shift I (pagi) pukul 06.00-14.00, shift II (siang) pukul 14.00-22.00, shift III (malam) pukul 22.00-06.00. Dibawah ini adalah alternatif model pembagian shift kerja, yaitu :

a. 3 shift kerja perputaran 8 jam dan akhir minggu libur yaitu jadwal kerja dibagi menjadi 3 shift (shift pagi pk.06.00, shift siang pk.14.00-22.00, shift malam 22.0006.00)

b. 3 shift kerja perputaran 2-2-2 yaitu 2 hari shift pagi, 2 hari shift siang, 2 hari shift malam, 2 hari libur selanjutnya kembali lagi ke shift pagi

c. 3 shift kerja, perputaran shift 2-2-3 yaitu 2 hari shift pagi, 2 hari shift siang, 3 hari shift malam, 2 hari libur selanjutnya kembali ke shift pagi

d. 2 shift kerja, 3 hari shift kerja dan 3 hari libur yaitu 3 hari shift pagi, 3 hari libur, 3 hari shift malam, 3 hari libur selanjutnya kembali lagi ke shift pagi 
e. 2 shift kerja, setiap minggu berbeda libur.

\section{Terapi Musik dan Aromaterapi}

Terapi adalah usaha untuk memulihkan kesehatan seseorang yang sedang sakit. Menurut Dileo, 2005, mengatakan bahwa terapi music merupakan praktek berbasis bukti secara fisik, fisiologi, dan sosial. Musik dikenal sebagai terapi yang sejak dahulu sebagai penyembuh beban fisik, dan beban mental. Seorang ahli terapi menganjurkan awal untuk memulai, atau menerapkan music sebagai terapi untuk menghilangkan, dan mengurangi tingkat stres dianjurkan selama 3 hari atau lebih, dan selanjutnya music dapat dijadikan rutinitas kebutuhan untuk menghilangkan stres. Penyakit yang bisa disembuhkan melalui terapi musik, yaitu : stres, sakit kronis, insomnia, sakit kardiovaskular, serangan rasa panic, takut, marah, sedih, kesakitan saat melahirkan, kanker, frustasi, hiperaktif, dan autis. Terapi musik mampu mengurangi gangguan fisik, seperti memperlambat gelombang otak, berdampak baik untuk pernapasan, detak, tekanan darah, membuat suasana hati menjadi baik, dan mudah tidur.

Menurut (Huck, 2008) bau berpengaruh langsung terhadap otak manusia. Hidung manusia memiliki kemampuan untuk membedakan lebih dari 100.000 bau yang berbeda yang mempengaruhi dan terjadi tanpa disadari. Bau-bau mempengaruhi bagian otak yang berkaitan dengan suasana hati, emosi, ingatan, dan pembelajaran.

\section{Metode NASA-TLX}

Metode untuk mengukur beban kerja mental dapat diklasifikasikan atas metode obyektif dan metode subyektif. Dalam metode obyektif, beban kerja mental di ukur dengan melihat berbagai kriteria fisiologi kerja. Sedangkan metode subyektif, pengukuran beban kerja mental didasarkan pada persepsi pekerja dengan justifikasi pengukuran. Metode NASATLX dikembangkan oleh Sandra. G Hart dari NASA-Ames Research Centre dan Lowell E. Staveland dari San Jose State University tahun 1981. Metode ini melakukan pengukuran multidimensional dengan mempertimbangkan bobot dan tingkatan. Tingkat faktor pertama berhubungan dengan pekerjaan yang dilakukan, sedangkan tiga faktor lainnya berhubungan dengan subyek.

\section{METODE}

Metode NASA-TLX(National Aeronautics and Space Administration Task Load Index) merupakan metode yang digunakan untuk menganalisis beban kerja mental yang dihadapi oleh pekerja yang harus melakukan berbagai aktivitas dalam pekerjaannya. Metode NASA- TLX dikembangkan oleh Sandra G. dari NASA-ames research center dan Lowell E. Staveland dari San Jose state university pada tahun 1981. Metode ini di kembangkan berdasarkan munculnya kebutuhan pengukuran subjektif yang terdiri dari skala Sembilan faktor ( Kesulitan tugas, tekanan waktu, jenis aktivitas, usaha fisik, usaha mental, performansi, frustasi, stress dan kelelahan). Dari Sembilan faktor ini disederhanakan lagi menjadi 6 yaitu Kebutuhan Fisik (KF), Kebutuhan Mental (KM), Kebutuhan Waktu (KW), Performansi (PF), Usaha (U) dan Tingkat Frustasi (TF). Data didapatkan dari kuisioner NASA-TLX yang dibagikan kepada karyawan quality control. Pada metode NASATLX dilakukan dua tahapan yaitu tahap pemberian bobot (weights) dan tahap pemberian peringkat (ratings), yaitu :

1. Tahap pembobotan.

Pada tahap ini, karyawan memilih satu diskriptor yang berpengaruh bagi karyawan. Pada saat bekerja dari setiap pasangan deskriptor yang ada dan terdapat 15 pasangan diskriptor. Pilihan-pilihan deskriptor tersebut kemudian diolah untuk menghitung bobot bagi masing-masing diskriptor dan boot ini akan digunakan pada tahap kedua

2. Tahap pemberian peringkat.

Pada tahap ini karyawan akan memberikan peringkat pada setiap diskriptor sesuai dengan beban kerja yang dirasakan subjek berkaitan dengan diskriptor tersebut dengan rentang skala peringkat 0-100. 


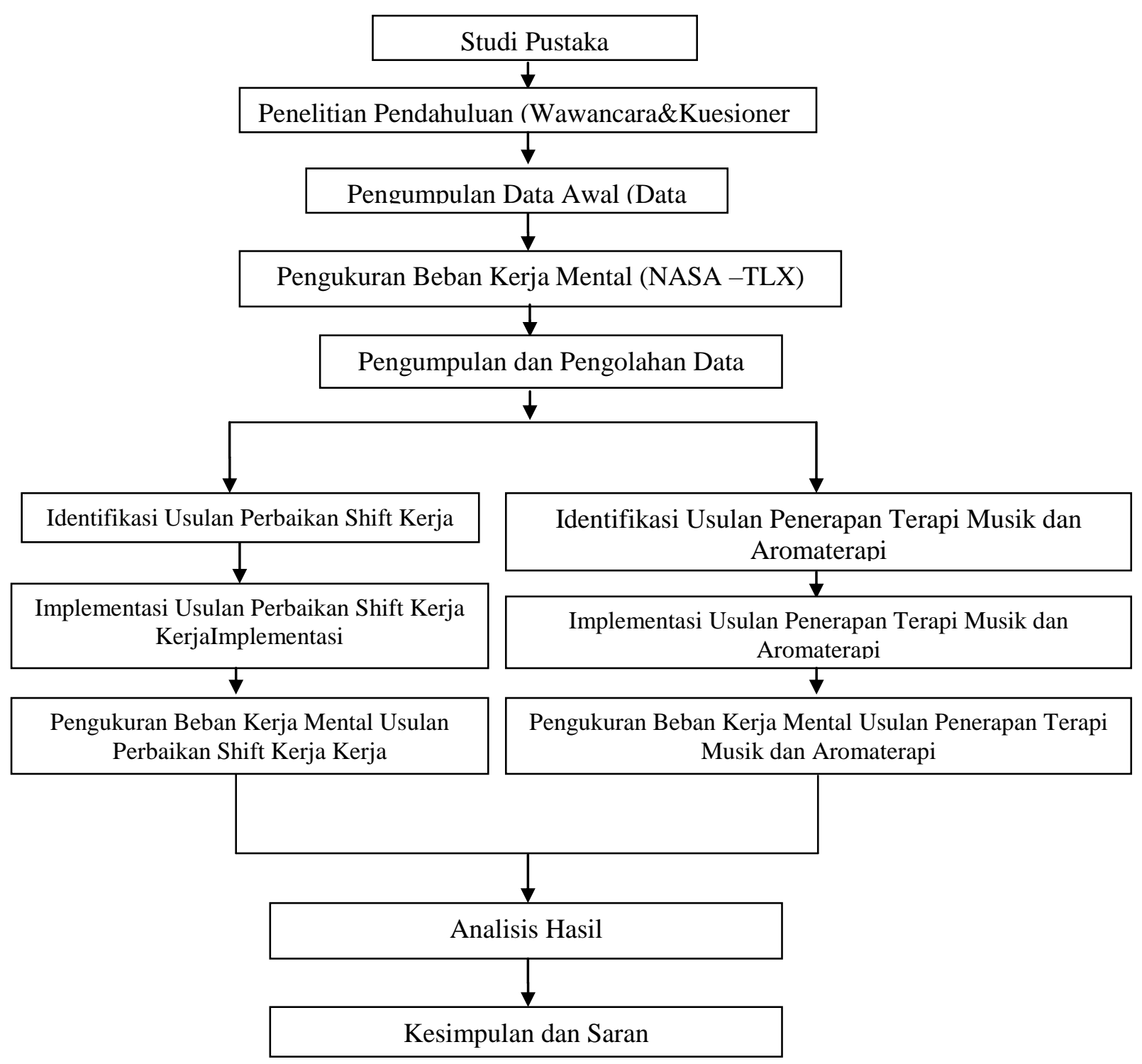

Gambar 1. Diagram Metode Penelitian 


\section{HASIL DAN PEMBAHASAN}

\section{Tahap Pemberian Peringkat (Ratings)}

Pada tahap ini, karyawan memberikan peringkat pada 6 kategori sesuai dengan yang dirasakan selama menjalani pekerjaan. Pada masing-masing faktor terdapat skala 0-100 atau rendah sampai dengan tinggi. Keenam kategori:

a. Mental Demands (MD)

Seberapa besar usaha mental yang dibutuhkan untuk menyelesaikan pekerjaan ini?

b. Physical Demands (PD)

Seberapa besar usaha fisik yang dibutuhkan untuk menyelesaikan pekerjaan ini?

c. Temporal Demands (TD)

Seberapa besar tekanan yang dirasakan dengan waktu untuk menyelesaikan pekerjaan ini?

d. Own Performance (OP)

Seberapa besar tingkat keberhasilan yang dibutuhkan untuk menyelesaikan pekerjaan ini?

e. Effort (EF)

Seberapa besar kerja mental dan fisik yang dibutuhkan untuk menyelesaikan pekerjaan ini?

f. Frustation (FR)

Seberapa besar kecemasan, perasaan tertekan, dan stress yang dirasakan untuk menyelesaikan pekerjaan ini?

\section{Tahap Pemberian Bobot (Weights)}

Pada tahap ini, dilakukan perbandingan pada masing-masing faktor. Dengan memilih pasangan kategori yang lebih berpengaruh atau dominan menjadi sumber beban kerja mental dari pekerjaan yang dilakukan.Pada saat bekerja dari setiap pasangan deskriptor yang ada dan terdapat 15 pasangan diskriptor. Pilihan-pilihan descriptor tersebut kemudian diolah untuk menghitung bobot bagi masing-masing diskriptor dan bobot ini akan digunakan pada tahap kedua.

Contoh pengisian kuesioner NASA-TLX tahap pembobotan :

\begin{tabular}{ll}
\hline KF/KM & KM \\
\hline
\end{tabular}

Apabila menurut anda, Kebutuhan Mental (KM) labih dominan dari pada Kebutuhan Fisik (KF) maka tulis KM pada kolom yang tersedia.

\section{Pengolahan Data Beban Kerja Mental}

Pengolahan data pada tahap ini, sampai dengan didapatkan tingkat beban kerja mental sebagai berikut :

a. Menghitung perbandingan peringkat antar deskriptor yang berpasangan kemudian menjumlahkan hasil perbandingan tersebut untuk setiap deskriptor terpilih. Dengan demikian, diperoleh 6 nilai bobot dari 6 deskriptor yang ada.

b. Menghitung beban kerja yang ditimbulkan oleh setiap deskriptor WWL (Weighted Workload ) dengan persamaan : WWL $=\sum$ $\left(\right.$ rating $_{\mathrm{i}} \mathrm{x}$ bobot $_{\mathrm{i}}$ )

c. Menghitung rata-rata WWL (Weighted

Workload) dengan membagi WWL

(Weighted Workload) tersebut dengan jumlah total bobot yaitu 15

\section{$\overline{W W L}=W W l / 15$}

Rentang skala peringkat pada setiap diskriptor terhadap nilai rata-rata WWL (Weighted Workload) beban kerja mental dapat diasumsikan bahwa, nilai skala $\leq 40$ beban kerja mental rendah, 40-70 beban kerja mental sedang dan $\geq 70$ beban kerja mental tinggi.

Tabel 1. Rekapitulasi Nilai Rata-rata Beban Kerja Mental Kondisi Awal

\begin{tabular}{lccc}
\hline \multicolumn{1}{c}{ Nama } & $\begin{array}{c}\text { Rata-rata W WL } \\
\text { (Weighted } \\
\text { Workload) Shift Pagi }\end{array}$ & $\begin{array}{c}\text { Rata-rata W WL } \\
\text { (Weighted Workload) } \\
\text { Shift Siang }\end{array}$ & $\begin{array}{c}\text { Rata-rata W WL } \\
\text { (Weighted } \\
\text { Workload) } \\
\text { Shift Malam }\end{array}$ \\
\hline Nico Demus G.T & 74 & 74,67 & 78,67 \\
\hline Imam Supriyatno & 74,67 & 74 & 78 \\
\hline Agustinus Billy & 74 & 75,33 & 77,33 \\
\hline Firman Ardiansyah & 76 & 74 & 75,33 \\
\hline Supriyanto & 72,67 & 78,67 & 76,67 \\
\hline
\end{tabular}




\begin{tabular}{lccc}
\hline Trimanto & 72 & 76 & 77,33 \\
\hline Anang Sugiana & 71,33 & 73,33 & 78,67 \\
\hline Peri Pebrianto & 74,67 & 74 & 77,33 \\
\hline Nazarudin & 73,33 & 73,33 & 76,67 \\
\hline Junaedi & 74,67 & 73,33 & 74 \\
\hline Agus Berkah & 72,67 & 75,33 & 80 \\
\hline Suratno & 72,67 & 74,67 & 80 \\
\hline Mugimin & 74,67 & 77,33 & 79,33 \\
\hline Anto Hendriyanto & 74 & 75,33 & 77,33 \\
\hline Yulianto & 75,33 & 76 & 78,67 \\
\hline Gunawan & 74 & 73,33 & 74 \\
\hline Ahmad Saidi & 76,67 & 74 & 77,33 \\
\hline Zaenal Aripin & 73,33 & 76,67 & 75,33 \\
\hline Rachmadi & 74,67 & 76,67 & 76 \\
\hline Sigit Purwoko & 72,67 & 77,33 & 77,33 \\
\hline Agus. S & 74 & 73,33 & 78,67 \\
\hline Wahyudin & 72 & 74,67 & 74 \\
\hline Imam Wahyudi & 73,33 & 72,67 & 74,67 \\
\hline Suseno & 72,67 & 74,67 & $\mathbf{7 7}$ \\
\hline Rata-rata & $\mathbf{7 3 , 7 5}$ & $\mathbf{7 4 , 9 4}$ & \\
\hline
\end{tabular}

4. Penerapan Usulan Perbaikan Shift Kerja, Terapi Musik dan Aromaterapi

Analisis beban kerja mental awal hasil WWL (Weighted Workload ) shift pagi 73,75, shift siang 74,94 dan shift malam 77,00. Karyawan pada shift malam paling tinggi mengalami beban kerja mental, ini terjadi karena pembagian shift kerja yang tidak teratur. Maka dilakukan usulan perbaikan shift kerja yang telah disesuaikan dengan kondisi shift kerja awal yaitu shift kerja dengan model 3 shift kerja perputaran shift 2-2-2 dan perputaran shift 8 jam ( 2 hari shift pagi, 2 hari shift siang, 2 hari shift malam, 2 hari libur selanjutnya kembali lagi ke shift pagi ).

Berdasarkan hasil penyebaran kuesioner terapi musik dan aromaterapi dipilih 3 besar jenis musik yang paling disukai yaitu dangdut, pop dan rock. Dan jenis aromaterapi yang paling disukai yaitu lemon. Kemudian dilakukan implemtasi usulan perbaikan shift kerja dan implementasi terapi musik dan aromaterapi.

Tabel 2. Rekapitulasi Keseluruhan Hasil Pengukuran Beban Kerja Mental

\begin{tabular}{lccc}
\hline & Shift Pagi & Shift Siang & Shift Malam \\
\hline $\begin{array}{l}\text { Sebelum Usulan perbaikan } \\
\text { shift kerja, penerapan terapi } \\
\text { musik dan aromaterapi }\end{array}$ & 73,75 & 74,94 & 77 \\
\hline Usulan perbaikan shift kerja & 57,86 & 58,53 & 58,92 \\
\hline $\begin{array}{l}\text { Usulan penerapan terapi } \\
\text { musik dan aromaterapi }\end{array}$ & $\mathbf{5 6 , 3 1}$ & $\mathbf{5 7 , 4 0}$ & $\mathbf{5 8 , 4 1}$ \\
\hline
\end{tabular}

Hasil rekapitulasi usulan perbaikan shift kerja terjadi penurunan nilai beban kerja mental yaitu shift pagi 57,86 , shift siang 58,53 , shift malam 58,92. Dan terjadi penurunan lagi ketika dilakukan usulan penerapan terapi musik dan aromaterapi yaitu shift pagi 56,31 , shift siang 57,40, shift malam 58,41.

Dan dapat disimpulkan bahwa usulan perbaikan shift kerja dan usulan penerapan terapi musik dan aromaterapi dapat menurunkan beban kerja mental karyawan bagian quality control.

\section{Tinjauan Hasil Penelitian Terdahulu}

Skripsi pengukuran beban kerja mental perawat (bagian penyakit dalam) oleh Apriansyah, tahun 2008. Pengukuran beban kerja mental dilakukan di Siloam Hospitals Lippo Karawaci lantai 8 bagian Bethsaida, hari dimana para perawat bekerja menggunakan 
metode NASA-TLX diperoleh hasilnya analisis perbandingan beban kerja mental shift pagi, siang dan malam pada kondisi awal.

Tabel 3. Rekapitulasi Keseluruhan Hasil Pengukuran Beban Kerja Mental

\begin{tabular}{lccc}
\hline & Kondisi Awal & $\begin{array}{c}\text { Perbaikan Shift } \\
\text { Kerja }\end{array}$ & $\begin{array}{c}\text { Penerapan Terapi Tawa dan } \\
\text { Senam Yoga }\end{array}$ \\
\hline $\begin{array}{l}\text { Rata-rata dari Rata-rata } \\
\text { WWL Shift Pagi }\end{array}$ & 73.89 & 62.85 & 57.79 \\
\hline $\begin{array}{l}\text { Rata-rata dari Rata-rata } \\
\text { WWL Shift Siang }\end{array}$ & 74.91 & 64.43 & 58.51 \\
\hline $\begin{array}{l}\text { Rata-rata dari Rata-rata } \\
\text { WWL Shift Malam }\end{array}$ & 77.01 & 64.72 & 59.12 \\
\hline
\end{tabular}

Hasil rekapitulasi usulan perbaikan shift kerja terjadi penurunan nilai beban kerja mental yaitu shift pagi 62.85 , shift siang 64.43 , shift malam 64.72. Dan terjadi penurunan lagi ketika dilakukan usulan penerapan terapi tawa dan senam yoga yaitu shift pagi 57.79 , shift siang 58.51, shift malam 59.12. Dapat disimpulkan bahwa usulan perbaikan shift kerja dan usulan penerapan terapi tawa dan senam yoga dapat menurunkan beban kerja mental perawat, di Siloam Hospitals Lippo Karawaci lantai 8 bagian Bethsaida. Dan pengukuran beban kerja mental perawat (bagian penyakit dalam) oleh Apriansyah, tahun 2008 dengan penelitian ini yaitu pengukuran beban kerja karyawan menggunakan metode NASA-TLX di PT. TRANKA KABEL bagian Quality Control hasilnya mengalami penurunan beban kerja mental karyawan.

\section{SIMPULAN DAN SARAN}

Berdasarkan hasil pengolahan data dan analisis, maka dapat diambil kesimpulan sebagai berikut:

1. Rata-rata WWL (Weighted Workload) beban kerja mental karyawan pada sebelum usulan perbaikan shift kerja dan penerapan terapi musik \& aromaterapi adalah shift pagi sebesar 73,75, shift siang sebesar 74,94 dan shift malam sebesar 77. Hasil Rata-rata WWL (Weighted Workload) beban kerja mental karyawan pada shift pagi, shift siang dan shift malam menunjukkan beban kerja mental tinggi.

2. Untuk mengatasi beban kerja mental yang tinggi dilakukan perbaikan shift kerja serta penerapan terapi musik dan aromaterapi.
Untuk usulan perbaikan shift kerja dipilih alternatif model 3 shift kerja perputaran shift 2-2-2 dan perputaran shift 8 jam (2 hari shift pagi, 2 hari shift siang, 2 hari shift malam, 2 hari libur selanjutnya kembali lagi ke shift pagi ).Hasil analisa beban kerja mental setelah perbaikan shift kerja dan penerapan terapi musik \& aromaterapi terjadi penurunan. Nilai rata-rata WWL (Weighted Workload) pada shift pagi sebesar 56,31, shift siang sebesar 57,40dan shift malam sebesar 58,41. Dapat disimpulkan bahwa beban kerja mental karyawan mengalami penurunan.

3. Pengukuran beban kerja mental perawat (bagian penyakit dalam) oleh Apriansyah, tahun 2008 dengan penelitian ini yaitu pengukuran beban kerja karyawan menggunakan metode NASA-TLX di PT. TRANKA KABEL bagian Quality Control hasilnya sama yaitu menunjukan penurunan beban kerja mental karyawan.

\section{REFERENSI}

Apriansyah. (2008). Pengukuran Beban Kerja Mental Perawat (Bagian Penyakit Dalam) Tarwaka et. Al. 2004. Ergonomik, Untuk Keselamatan, Kesehatan Kerja dan Produktivitas. Uniba Press: Jakarta.

Bagas, P. (1999). Desain Produk Industri. Yayasan Delapan-Sepuluh. Bandung

Bridger,R.S.(1995). Introduction to Ergonomics. McGraw-Hill, Inc: Singapore.

Hart, S. and Staveland, L. (1988). Development of NASA-TLX : Results of Empirical and Theoretical Research. In P. Hancock and 
N. Meshkati (eds.), Human Mental Workload. Amsterdam.

Meshkati, N., Hancock, P.A., \& Rahimi,M. (1989). Techniques of mental workload assessment. In: J. Wilson (Ed.). Evaluation of Human Work: Practical Ergonomics Methodology. London: Taylor and Francis

Sanders, M. S. dan Ernest J. M.C. (1993). Human Factors in Engineering and Design $7^{\text {th }} e d$. . New York: Mc-Graw Hill, Inc.

Lucki.K.H, "Pengukuran Beban Kerja dengan Metode NASA-TALK Load Index di CV.Gimera Jaya Bandung"

Fariz.H, Sugiharto.P, dan Anizar, "Pengukuran Beban Kerja Perawat Menggunakan Metode NASA-TLX di Rumah Sakit XYZ' ,E-Jurnal Teknik Industri FT USU Vol.II No. 1, Mei 2013 pp.42-47

Miranti.S.A, Caecillia.S.W, dan Yuniar. Tingkat Beban Kerja Mental Masinis berdasarkan
NASA-TLX (Task Load Index) di PT.KAI Daop.II Bandung", Jurnal Online Institut Teknologi Nasional Teknik Industri Itenas,No.1,Vol.1,Juni 2013 